\title{
A Review on Use of Micronutrients in Tropical and Subtropical Fruit Crops
}

\author{
R. K. Jat ${ }^{1}$, Mukesh Kumar ${ }^{2 *}$, Mohan Lal Jat ${ }^{3}$ and Jitendra Singh Shivran ${ }^{4}$ \\ ${ }^{1}$ Department of Fruit Science, College of Horticulture, \\ SDAU, Jagudan, Mehsana, Gujarat, India \\ ${ }^{2}$ Department of Natural Resource Management, College of Horticulture, \\ SDAU, Jagudan, Mehsana, Gujarat, India \\ ${ }^{3}$ Department of Horticulture, College of Agriculture, CCS HAU, Hisar, Haryana, India \\ ${ }^{4}$ Department of Horticulture, College of Agriculture, GBPU\&T, Pantnagar, \\ Uttarakhand, India \\ *Corresponding author
}

\section{A B S T R A C T}

\begin{tabular}{|c|}
\hline $\begin{array}{l}\text { K e y w o r d s } \\
\text { Micronutrients, } \\
\text { Fruit crops, } \\
\text { Fertilizers }\end{array}$ \\
\hline Article Info \\
\hline $\begin{array}{l}\text { Accepted: } \\
23 \text { April } 2020 \\
\text { Available Online: } \\
10 \text { May } 2020\end{array}$ \\
\hline
\end{tabular}

Plant nutrition plays a major role in quantitative and qualitative crop production in bringing sustainability and plants require seventeen essential elements for their normal growth and development. Among these, those elements required smaller in quantity is called micronutrients $(\mathrm{Fe}, \mathrm{Cu}, \mathrm{Zn}, \mathrm{Mn}, \mathrm{B}, \mathrm{Cl}, \mathrm{Mo}$ and $\mathrm{Ni}$ ). Micronutrients are essentially as important as macronutrients to have better growth, yield and quality in plants. Micronutrients are involved in plant metabolism, nutrient regulation, reproductive growth, chlorophyll synthesis, production of carbohydrates, fruit and seed development, etc. They have assumed increasing importance in crop production under present exploitative agriculture system. Intensive cultivation of high yielding varieties and use of high analysis fertilizers disturb the nutrient balance in soil. As results, micronutrients become limiting factor for crop production. Horticultural crops suffer widely by iron and zinc deficiencies followed by other micronutrients deficiencies. Due to these deficiencies some healthy orchards are turning into unproductive plantation with poor quality fruit. Micronutrients are to be necessarily taken up by the plants from soil or supplemented through chemical fertilizers or through other sources by soil application or foliar application for good growth and yield of crops. These also maximize the efficient use of applied major nutrients. The present study is an attempt to review the literature and explore the proper use of micronutrients to mitigate the deficiency of particular element that has effects on production potential of tropical and subtropical fruit crops.

\section{Introduction}

In recent years, micronutrients gained profound significance in intensive cropping system for attaining higher yield and productivity. Micronutrients ( $\mathrm{Fe}, \mathrm{Cu}, \mathrm{Zn}, \mathrm{Mn}$, $\mathrm{B}, \mathrm{Cl}, \mathrm{Mo}$ and $\mathrm{Ni}$ ) are regarded as essential plant nutrients taken up by the plants in relatively lesser quantity. The importance of micronutrients in agriculture is truly well recognized and their uses have significantly contributed to the increased productivity of several crops (Tripathi et al., 2015). The adequate supply of micronutrients with macronutrients increases the yield and quality of production. The continuous use of high analysis fertilizers to gain the higher production disturbs the nutrient balance in 
soil. Micronutrients become limiting factor for crop production and their greater deficiencies causing serious concern in warning the sustainability of the intensive production systems. The deficiency of micronutrients has become major constraint to productivity, stability and sustainability of soils (Bell and Dell, 2008). Sometime, their acute deficiencies pose the problem of incurable nature (Kumar, 2002).

These also help in the uptake of major nutrients and play an active role in the plant metabolism process starting from cell wall development to respiration, photosynthesis, chlorophyll formation, enzyme activity, hormone synthesis, nitrogen fixation and reduction (Das, 2003). These nutrients also play decisive roles in humans concerning with our physical and mental development and how we respond to diseases. In the countries or regions where staple foods consist mainly of cereals, roots, and tubers grown in nutrientpoor soils, human micronutrient deficiency is widespread.

Fruits contain a wide range of different compounds like minerals, vitamins, etc. and the nutritive value of fruit depends on its composition. Although fruit plays a very significant role in human nutrition, the composition of fruit is such that it is not recommended as a sole source of nutrition. However, it can be used advantageously to supplement deficiencies in other foods. Micronutrient amendments into soil for crop uptake could contribute in lowering the impact of their deficiency in humans (Cakmak, 2008).

The improvement in quality of fruit might be due to the catalytic action of micronutrients particularly at higher concentrations. Hence the foliar application of micronutrients quickly increased the uptake of macronutrients in the tissues and organs and improves fruit quality (Anees et al., 2011). To ensure better growth, yield and quality through correcting deficiencies of micronutrients in fruit crops, foliar application of micronutrient is one of the tools and this method allows multiple applications at different time. In addition, there is reduced concern for nutrient loss, tie up, or fixation when compared to soil applications.

\section{Micronutrients}

Micronutrients, which include $\mathrm{Fe}, \mathrm{Cu}, \mathrm{Zn}$, $\mathrm{Mn}, \mathrm{B}, \mathrm{Cl}, \mathrm{Mo}$ and $\mathrm{Ni}$, are required in smaller amounts than the other essential nutrients or those essential elements required less than 0.1 per cent of plant dry matter is called micronutrient. The deficiencies of micronutrient may result in poor responses to the macronutrients. Deficiencies occur where soils are inherently poor in micronutrients or where soils have been degraded. Micronutrient deficiencies are often related to soil $\mathrm{pH}$. The functions and deficiency symptoms of important micronutrients observed in fruit crops discussed as under.

\section{Iron $(\mathrm{Fe})$}

Fe is an important element for the synthesis of chlorophyll. Plants deficient in Fe may exhibit pale colour of the younger leaves and veins remains green or interveinal chlorosis of the whole leaves. Moreover, papery white colour of the younger leaves occur under severe deficiency.

\section{Zinc (Zn)}

Zn plays a role in the regulation of plant growth and transformation of carbohydrates and is required for nucleic acid synthesis and enzyme activation. Common deficiency of $\mathrm{Zn}$ is interveinal chlorosis, first appear on the middle to young leaves. Rosetting commonly occurs in citrus fruit trees. 


\section{Copper (Cu)}

$\mathrm{Cu}$ is an essential part of the enzyme system that utilizes carbohydrates and proteins and is important for reproductive growth. $\mathrm{Cu}$ deficient plants may show dieback of shoot tips and old leaves develop brown spots. Male flowers sterility, delay flowering and senescence are the most important effects of copper deficiency.

\section{Manganese (Mn)}

$\mathrm{Mn}$ is essential for some enzyme activity and takes part in oxidation-reduction processes. When it is deficient, the symptoms are similar to Fe deficiency, with pale young leaves and green veins. Sometimes brown, black or grey spots are observed next to leaf veins.

\section{Boron (B)}

$\mathrm{B}$ is required for nucleic acid synthesis, pollen germination and the growth of the pollen tube. B promotes root development, enzyme activity and is associated with lignin synthesis, sugar transport, seed and cell wall formation, calcium uptake and proper water relations.

It imparts the drought tolerance to the crops. B deficient plants show curled, brittle leaves and discolored or cracked fruits. Leaf symptoms are usually found on leaf tips and terminal buds or youngest leaves, which become discoloured and may die under acute conditions of B deficiency.

Generally, soils contain sufficient levels of micronutrients to meet crop demands; however, in some areas micronutrients shortage occur and may limit yields. Some crops have a higher demand for certain micronutrients than others and should be considered in determining whether a micronutrient fertilizer should be applied or not. The relative responses of important tropical and subtropical fruit crops to micronutrients are reviewed as below.

\section{Mango}

Nehete et al., (2011) concluded that foliar application of $\mathrm{ZnSO}_{4} 1 \%+\mathrm{FeSO}_{4} 1 \%+$ borax $0.5 \%$ gave significantly maximum average fruit weight $(0.295 \mathrm{~kg})$, total number of fruits per tree (168) and yield $(49.54 \mathrm{~kg} /$ tree $)$. Whereas, maximum total sugar $(16.67 \%)$, reducing sugar $(6.03 \%)$, TSS $\left(19.00{ }^{\circ}\right.$ Brix) and ascorbic acid (32.80 $\mathrm{mg} / 100 \mathrm{~g}$ ) were also recorded in the same treatment in mango cv. Kesar. Bhatt et al., (2012) reported that the trees sprayed with $0.5 \%$ borax showed maximum fruit yield, fruit weight, fruit volume, TSS, reducing sugar, non-reducing sugar and ascorbic acid content in mango.

Krishnamoorthy and Hanif (2015) concluded that application of NPK @ 1.0:1.0:1.5 kg per tree $+50 \mathrm{~kg}$ FYM + foliar application of micronutrient formulation @ 0.5 per cent resulted in higher growth, yield and quality parameters. The yield per hectare was 20.99 percent higher than the application of NPK alone followed by 10.22 per cent yield increase obtained with foliar spraying of sulphate of potash 2 per cent than the control.

Pawar and Singh (2018) showed that the application of RDF + foliar spray of $\mathrm{ZnSO}_{4}$ @ $0.4 \%+\mathrm{CuSO}_{4} @ 0.2 \%$ + boric acid @0.2 $\%$ (2 sprays at just before flowering and marble stage) was found to be most effective for increasing number of fruits per panicle at pea and marble stage (9.67 and 4.58, respectively), yield per plant $(271.51 \mathrm{~kg})$, yield per hectare $(27151 \mathrm{~kg})$, per cent increase in yield $(56.40 \%)$, TSS (18.51 ${ }^{\circ}$ Brix), total sugar $(12.88 \%)$, ascorbic acid content (43.62 $\mathrm{mg} / 100 \mathrm{~g}$ pulp) with reduced acidity (0.149 $\%)$. 
The higher fruit weight $(221.98 \mathrm{~g})$, fruit length $(10.87 \mathrm{~cm})$ and fruit width $(6.54 \mathrm{~cm})$ were observed with the application of RDF + $10 \%$ sea weed sap (2 sprays at panicle emergence and marble stage) $+\mathrm{ZnSO}_{4} @ 200$ $\mathrm{g}+\mathrm{CuSO}_{4} @ 100 \mathrm{~g}+$ boric acid @ $100 \mathrm{~g}$ (soil application). Almost similar results were recorded by use of RDF + foliar spray of 0.4 $\%$ zinc sulphate + copper sulphate $(0.2 \%)+$ borax $(0.2 \%)$ and application of RDF + foliar spray of $0.4 \%$ zinc sulphate + boric acid $(0.2$ $\%$ )in mango (Haldavnekar et al., 2018)

\section{Banana}

Jeyabaskaran and Pandey (2008) stated that soil application of $\mathrm{Fe}\left(5 \mathrm{~g} \mathrm{FeSO}_{4}\right.$ per plant at 3 MAP), foliar applications of $\mathrm{Zn}(0.5 \%$ $\mathrm{ZnSO}_{4}$ each at 3,5 and $\left.7 \mathrm{MAP}\right)$ and $\mathrm{B}(10$ ppm boric acid each at 3,5 and 7 MAP) with recommended dose of NPK $\left(\mathrm{N}: \mathrm{P}_{2} \mathrm{O}_{5}: \mathrm{K}_{2} \mathrm{O}\right.$ $200: 50: 400 \mathrm{~g}$ per plant) produced the highest bunch weight and best quality fruits. Pathak et al., (2011) concluded that foliar application of $\mathrm{ZnSO}_{4} 0.5 \%+\mathrm{FeSO}_{4} 0.5 \%$ gave significantly maximum fingers per bunch (129.20), hands per bunch (9.20), bunch weight $(16.30 \mathrm{~kg})$ and yield $(40.75$ t/ha). Whereas, maximum TSS $\left(25.66^{\circ}\right.$ Brix $)$ and total sugar $(17.86 \%)$ were found by foliar application ofFeSO $0.5 \%$ and non-reducing sugar $(10.04 \%)$ was recorded with foliar application of $\mathrm{ZnSO}_{4} 0.5 \%+\mathrm{FeSO}_{4} 0.5 \%$ in banana cv. Martaman. Krishnamoorthy and Hanif (2017) revealed that the highest pseudostem height $(2.48 \mathrm{~m})$, pseudostem girth $(76 \mathrm{~cm})$, number of leaves per plant (18), leaf area index(4.72), finger weight (123 g), bunch weight $(20.10 \mathrm{~kg})$ and TSS $\left(16.6^{\circ}\right.$ Brix $)$ were recorded with application of Arka banana special micronutrients followed by foliar application micronutrients and soil application. The Arka banana special application through soil application $250 \mathrm{ml}$ solution (\%) on 45 days after planting, followed by foliar application 0.5 per cent on
5, 6, 7 and at shooting on hands recorded significantly highest yield (45.23 t/ha) over other two micronutrient application. Premalatha and Suresh (2019) indicated that foliar application of micronutrients mixture as 3 per cent micronutrient mixture and as 2 per cent micronutrient mixture with 3 times of spraying at 2, 4 and 6 months after planting significantly enhanced the quality attributing parameters of Nendran banana.

\section{Papaya}

Shekhar et al., (2010) observed that foliar application of $0.25 \% \mathrm{CuSO}_{4}+0.25 \%$ $\mathrm{MnSO}_{4}+0.1 \%$ borax gave maximum number of fruits per plant (30.67), average fruit weight $(1.30 \mathrm{~kg})$, fruit yield $(40.40$ $\mathrm{kg} / \mathrm{plant})$ as well as improved TSS $(9.60$ ${ }^{\circ}$ Brix) and total sugar $(9.72 \%)$ with minimum acidity $(0.053 \%)$ in papaya $\mathrm{cv}$. Washington. Singh et al., (2012) revealed that maximum fruit weight $(1.43 \mathrm{~kg})$, number of fruits per plant (25.92) and yield (37.20 kg/plant) were recorded with the foliar application of borax $0.50 \%+\mathrm{ZnSO}_{4} 0.25 \%$. Similarly, maximum TSS (6.81 ${ }^{\circ}$ Brix), total sugar $(6.88 \%)$, reducing sugar $(6.35 \%)$ and non-reducing sugar $(0.53 \%)$ were recorded in the same treatment in papaya cv. Ranchi. Parmer et al., (2017) recorded maximum growth characters like plant height, plant girth and leaf area and minimum days required for first flower initiation when papaya var. Red Lady plants were treated with $100 \%$ RDNK (200:250 $\mathrm{g} /$ plant) applied in 8 equal splits starting from $2^{\text {nd }}$ month after planting in 30 days interval with foliar application of $1 \%$ Grade-IV micronutrient at $2^{\text {nd }}, 4^{\text {th }}, 6^{\text {th }}$ and $8^{\text {th }}$ month after planting. Monika et al., (2018) revealed that foliar application of calcium $[0.5 \% \mathrm{Ca}$ $\left.\left(\mathrm{NO}_{3}\right)_{2}\right], \quad$ sulphur $\left(0.5 \quad \% \quad \mathrm{~K}_{2} \mathrm{SO}_{4}\right) \quad$ and micronutrients (zinc sulphate @ $0.5 \%$ and boric acid @ $0.1 \%$ ) along with the recommended dose of fertilizers recorded significantly the highest number of fruits 
(34.21), fruit weight $(1.39 \mathrm{~kg})$, fruit length $(29.96 \mathrm{~cm})$ and fruit circumference (41.34 $\mathrm{cm})$. The fruit yield $(47.54 \mathrm{~kg} /$ plant $)$ recorded in this treatment was 28.21 per cent higher than control in spite of the incidence of PRSV (31.26\%).Singh et al., (2018) revealed that foliar application of copper sulphate $0.25 \%+$ manganese sulphate $0.25 \%$ + NAA $30 \mathrm{ppm}+$ $\mathrm{GA}_{3} 60 \mathrm{ppm}$ attained maximum pooled value in terms of plant height $(139.99 \mathrm{~cm})$, stem girth $(42.69 \mathrm{~cm})$, number of leaves (29.52) whereas minimum days taken for initiation of first flower (103.83) with the spray of copper sulphate $0.25 \%+$ manganese sulphate $0.25 \%$.

\section{Guava}

Bhoyar and Ramdevputra (2012) revealed that maximum fruits per shoot (3.6) and fruit yield $(57.1 \mathrm{~kg} /$ tree $)$, TSS (13.6 ${ }^{\circ}$ Brix $)$, total sugar $(7.9 \%)$ and minimum acidity $(0.38 \%)$ were recorded when trees did foliar application of $0.5 \% \mathrm{ZnSO}_{4}+0.5 \% \mathrm{FeSO}_{4}+0.3 \%$ borax. Whereas, minimum fruit drop (53.6\%) was recorded with foliar application of $0.5 \%$ $\mathrm{FeSO}_{4}+0.3 \%$ borax, maximum ascorbic acid content $(225.0 \%)$ was recorded with $0.5 \%$ $\mathrm{FeSO}_{4}$ and pectin $(0.65 \%)$ was recorded with $0.3 \%$ borax in guava cv. L-49.

Gaur et al., (2014) reported maximum fruit length $(6.07 \mathrm{~cm})$, fruit width $(5.92 \mathrm{~cm})$, fruit weight (98.48 g), TSS (11.7 ${ }^{\circ}$ Brix $)$, total sugar (7.51\%), ascorbic acid (172 mg/100g) with minimum acidity $(0.3 \%)$ by foliar application of $0.4 \%$ borax on winter season guava cv. L49. Foliar application of $0.4 \%$ borax $+0.8 \%$ $\mathrm{FeSO}_{4}$ increased yield and quality parametersas reported by Hadda et al., (2014) in guava. Shreekant et al., (2017) recorded maximum yield and yield attributing characters with foliar application of borax 1.0 per cent. Zagade et al., (2017) recorded maximum number of fruits per tree (170), yield per tree $(35.57 \mathrm{~kg})$, yield per hectare (14.22 t), TSS (11.80 ${ }^{\circ}$ Brix), reducing sugar
$(4.52 \%)$ and total sugar $(7.40 \%)$ when guava plants were treated with foliar spray of zinc sulphate @ $1 \%$ treatment. However, maximum weight of fruit (193 g) and weight of pulp (153.60 g) were observed with application of $\mathrm{CuSO}_{4} @ 1 \%+\mathrm{FeSO}_{4} @ 1 \%+$ $\mathrm{ZnSO}_{4} @ 1 \%+$ borax@0.5\% treatment and minimum acidity $(0.35 \%)$ were observed with application of ferrous sulphate @ $1 \%$ treatment.

\section{Sapota}

Saraswathy et al., (2002) concluded that soil application of $50 \mathrm{~g} \mathrm{ZnSO}_{4}+25 \mathrm{~g}$ borax per tree along with foliar spray of $\mathrm{ZnSO}_{4} 0.5 \%+$ borax $0.3 \%$ gave significantly maximum single fruit weight $(86.52 \mathrm{~g})$, number of fruits per tree (930) and yield (59.13 kg/tree). Whereas, maximum TSS $\left(23.25^{\circ}\right.$ Brix), total sugar $(11.80 \%)$, reducing sugar $(9.41 \%)$ and ascorbic acid $(3.65 \mathrm{mg} / 100 \mathrm{~g})$ were also recorded with the same treatment in sapota cv. PKM-1.The morphophysiological parameters like photosynthetic rate, transpiration rate and stomatal conductance were increased by higher level of micronutrients i.e. $\mathrm{FeSO}_{4} 2 \%+\mathrm{ZnSO}_{4} 2 \%+$ borax $1 \%$ treatment (Ghumare et al., 2013). The foliar application of $0.5 \% \mathrm{ZnSO}_{4}+0.5$ $\% \mathrm{FeSO}_{4}+0.3 \%$ borax shown significant increase of plant vegetative growth parameters and yield over control (Thirupathaiah et al., 2017).

\section{Citrus}

Venu et al., (2014) stated that the maximum fruit set $(49.33 \%)$, number of fruits per shoot (8.53\%), number of fruits per tree (925.0), fruit yield $(27.07 \mathrm{~kg} /$ plant $)$ and minimum fruit drop $(24.33 \%)$ were recorded with the foliar application of $\mathrm{ZnSO}_{4} 0.5 \%+\mathrm{FeSO}_{4} 0.4 \%+$ borax $0.4 \%$ in acid lime cv. Kagzi. Gurung et al., (2016) concluded that foliar application of $\mathrm{GA}_{3} @ 15$ ppm along with zinc $(0.5 \%)$ and 
boron $(0.1 \%)$ improved growth morphology, fruit yield and fruit yield attributes with better quality in Darjeeling Mandarin. Soni et al., (2017) revealed that foliar application of $\mathrm{CuSO}_{4}(0.4 \%)$ at pea stage and gravel stage increased the fruit retention to the extent of 46 per cent as compared to control 23 per cent only.

The maximum number of fruits per plant (598.67), fruit retention (25.95\%), size of fruits (fruit length $6.28 \mathrm{~cm}$ and breadth 7.15 $\mathrm{cm})$, average fruit weight $(163.67 \mathrm{~g})$ and fruit yield per plant $(97.83 \mathrm{~kg}$ ) was recorded along with minimum June (39 \%) and pre-harvest (12\%) fruit drop when Kinnow mandarin plants were sprayed with urea $1.0 \%+\mathrm{K}_{2} \mathrm{SO}_{4}$ $1.0 \%+\mathrm{ZnSO}_{4} 0.5 \%+\mathrm{FeSO}_{4} 0.5 \%+$ $\mathrm{H}_{3} \mathrm{BO}_{3} 0.2 \%$ (Reetika et al., 2018). Tagad et al., (2018) stated that foliar spray of $\mathrm{GA}_{3}(50$ $\mathrm{ppm})+\mathrm{ZnSO}_{4}(1 \%)+\mathrm{FeSO}_{4}(1 \%)$ improved fruit quality parameters of acid lime.

\section{Pomegranate}

Hasani et al., (2012) studied the effects of zinc and manganese as foliar spray on pomegranate yield, fruit quality and leaf minerals. They stated that the Mn sprays had positive significant effects on the fruit yield, the aril/peel ratio, TSS, weight of 100 arils, juice content of arils, anthocyanin index, fruit diameter and leaf area. Zn effects were also significant for TSS, TSS/TA ratio, juice content of arils and leaf area. Foliar spray of $\mathrm{Mn}$ significantly increased $\mathrm{Mn}$ and $\mathrm{N}$ but decreased $\mathrm{Zn}$ and $\mathrm{Cu}$ concentrations in leaves. Moreover, foliar sprays of $\mathrm{Zn}$ significantly increased $\mathrm{Zn}$ but decreased $\mathrm{Mn}$ and $\mathrm{P}$ concentrations in the leaves. Dhurve et al., (2018) studied the effect of foliar application of $\mathrm{Zn}$ and $\mathrm{B}$ on yield parameters and found that highest number of fruit per plant (57.67), fruit weight $(301.74 \mathrm{~g})$ and yield/plant (18.44 $\mathrm{kg}$ ) in foliar spray of $0.4 \%$ boric acid $+0.4 \%$ zinc sulphate treatment. Gawade et al., (2018) conducted an experiment at Mahatma Phule Krishi Vidyapeeth, Rahuri on pomegranate and recorded maximum yield (26.87 $\mathrm{kg} /$ plant), number of fruits (101.33) and average weight of fruit (272.00) in recommended dose of fertilizers $(625 \mathrm{~N}: 250$ P: $250 \mathrm{~K} \mathrm{~g}$ per tree) along with each 5 sprays of Sujala (NPK 19:19:19 @ 0.5\%) and micronutrient mixture "Microla" (0.2 \%) treatment followed by RDF alongwith Sujala, Microla (3 sprays) and phosphate solubilising bacteria "Biola" treatment. Yadavet al., (2018) revealed that application of 0.4 per cent zinc sulphate +0.4 per cent boric acid + 0.4 per cent ferrous sulphate significantly increased fruit diameter, fruit weight, fruit volume, number of arils per fruit, fruit set percent, number of fruit per plant and yield as compared to control which was closely followed by zinc sulphate @ 0.4 per cent + boric acid@0.4 per cent + ferrous sulphate @ 0.2 per cent treatment.

Further this treatment has also enhanced TSS/Acid ratio, ascorbic acid, juice per cent and sensory score and significantly reduced days taken to first harvesting, total days taken to complete harvesting and acidity per cent of fruits. Gaikwad et al., (2019) revealed that foliar application of $\mathrm{GA}_{3} @ 75 \mathrm{ppm}$ and boron $0.3 \%$ at 90,105 and 135 days after flowering may be beneficial for producing higher yield and yield attributing characters.

\section{Aonla}

Khan et al., (2009) studied the effect of foliar application of micronutrients and thiourea on vegetative growth, fruit yield and quality of aonla cv. Narendra Aonla-6 and concluded that maximum vegetative growth (plant height, girth and spread), fruit retention, yield, size, weight and volume of fruits were obtained with foliar application of $\mathrm{ZnSO}_{4}(0.5$ $\%)+$ thiourea $(0.1 \%)$, closely followed by borax $(0.25 \%)+$ thiourea $(0.1 \%)$. Meena et 
al., (2014) observed highest plant height increment $(0.95 \mathrm{~m})$, canopy spread E-W and $\mathrm{N}-\mathrm{S}$ increment $(0.89 \mathrm{~m}$ and $0.86 \mathrm{~m})$, canopy height increment $(0.93 \mathrm{~m})$, fruit volume $(44.10 \mathrm{ml})$, fruit length $(4.20 \mathrm{~cm})$, fruit diameter $(4.46 \mathrm{~cm})$, pulp thickness $(1.41 \mathrm{~cm})$, reducing sugar $(3.56 \%)$, non-reducing sugar $(2.99 \%)$, juice $(78.22 \%)$, fruit weight $(45.20$ g) and yield per tree $(42.70 \mathrm{~kg})$ with the combined spray of $0.6 \%$ calcium nitrate +0.4 $\%$ borax $+0.8 \%$ zinc sulphate followed by $0.3 \%$ calcium nitrate $+0.2 \%$ borax $+0.4 \%$ zinc sulphate treatment. Mishra et al., (2017) concluded that foliar feeding of $\mathrm{CuSO}_{4}$ $(0.4 \%)+\mathrm{ZnSO}_{4}(0.25 \%)+$ borax $(0.25 \%)$ gave best result for the production of maximum fruit yield and better quality of aonla fruits. Patel et al., (2018) stated that foliar application of $\mathrm{CuSO}_{4}(0.4 \%)+\mathrm{ZnSO}_{4}$ $(0.5 \%)$ improved yield and yield attributing characters.

\section{Ber}

Kamble et al., (1994) indicated that foliar spray of iron, manganese, zinc, and boron increased fruit set (\%) and fruit retention. Meena et al., (2008) stated that foliar application of ferrous sulphate and borax at pea stage @ 0.6 per cent produced maximum average fruit weight, fruit length, fruit breadth, pulp weight, stone weight, pulp to stone weight ratio, fruit yield and net returns and benefit cost ratio of ber than the control and 0.3 per cent spray in ber. Yadav et al., (2008) recorded maximum fruit quality parameters when ber trees treated with soil application of $40 \mathrm{~g}$ FeEDTA /plant.

\section{Grape}

Grape yield was exceptionally higher in response to foliar application of $\mathrm{Mg}, \mathrm{Fe}$ and $\mathrm{B}$ compared to other treatments. The improved yield in response to $\mathrm{B}$ and $\mathrm{Mg}$ was related to an increase in the berry weight, while in case of $\mathrm{Fe}$ it was related to an increase in the number of berries/bunch. Fruit quality of grape in terms of total soluble solids, acidity, juice and tannin content was better for nutrient (B, Fe, Urea and $\mathrm{Mg}$ ) sprayed as compared to control in grapevines (Usha and Singh, 2002). Subramoniam et al., (2006) observed higher juice content, TSS, titratable acidity, specific gravity, total sugar and TSS/acidity ratio by application of recommended dose of $\mathrm{N}, \mathrm{P}$ and $\mathrm{K}$ fertilizers along with foliar sprays of $\mathrm{ZnSO}_{4}(0.2 \%)+$ boric acid $(0.2 \%)+\mathrm{FeSO}_{4}(0.2 \%)+\mathrm{MnSO}_{4}$ $(0.2 \%)+\mathrm{MgSO}_{4}(0.5 \%)+\mathrm{CaCl}_{2}(0.5 \%)+$ $\mathrm{KNO}_{3}(0.5 \%)+$ urea $(1 \%)$ at blooming and 15 days after blooming stages. From the foregoing reviews, it can be concluded that the role of micronutrients have a significant effect on fruit plants and their application in adequate quantity through foliar and/or soil application with the required recommended dose of fertilizers (NPK) significant improves in vegetative growth, fruit yield and quality of fruit crops.

\section{References}

Anees, M., Tahir, F.M., Shahzad, J. and Mahmood, N. 2011. Effect of foliar application of micronutrients on the quality of mango (Mangifera indica L.) cv. Dusehri fruit. Mycopathologia.9 (1): 25-28.

Bell, R.W. and Dell, B. 2008. Micronutrients for Sustainable Food, Feed, Fibre and Bioenergy Production. Paris, France. International Fertilizer Industry Association. p-167.

Bhatt, A., Mishra, N.K., Mishra, D.S. and Singh, C.P. 2012. Foliar application of potassium, calcium, zinc and boron enhanced yield, quality and shelf life of mango. Hort Flora Research Spectrum.1 (4): 300-305.

Bhoyar, M. G. and Ramdevputra, M. V. 2012. Effect of foliar spray of zinc, iron and 
boron on growth, yield and quality characters of guava (Psidium guajava L.) cv. L- 49. Journal of Applied and Natural Science. 8 (2): 701-704.

Cakmak, I. 2008. Enrichment of cereal grains with zinc: Agronomic or genetic biofortification? Plant Soil. 302: 1-17.

Das, D.K. 2003. 'Micronutrients: Their behaviors in soils and plants'. Kalyani Publishers, Ludhiana. pp. 1-2.

Dhurve, M.K., Sharma, T.R., Bhooriya, M. and Lodha, G. 2018. Effect of foliar application of zinc and boron on growth, reproductive and yield of pomegranate cv. Ganesh in hasta bahar. International Journal of Chemical Studies. 6 (5): 499-503.

Gaikwad, P.S., Tambe, T.B. and Gaonkar, Y.A. 2019. Effect of foliar application of chemicals on yield of pomegranate cv. Bhagwa. International Journal of Chemical Studies. 7 (1): 524-528.

Gaur, B., Beer Karma; Hada, T.S., Kanth, N. and Syamal, M.M. 2014. Studies on the effect of foliar application of nutrients and $\mathrm{GA}_{3}$ on fruit yield and quality of winter season guava. An International quarterly Journal of Environmental Sciences. VI: 479-483.

Gawade, S.N., Kale, A.P., Shaikh, J.A. and Sharma, R.C. 2018. Study on nutrient package for pomegranate (Punica granatum L.). Indian Journal of Agricultural Research.52 (2): 199-202.

Ghumare, V.S., Padhiar, B.V., Dilip, K. and Babita, K. 2013. Study of micronutrient sprays on physiological parameters and leaf nutrient status of sapota cv. Kalipatti. The Asian Journal of Horticulture. 8 (2): 612-615.

Gurung, S., Mahato, S.K., Suresh, C.P. and Chetrri, B. 2016. Impact of foliar application of growth regulators and micronutrients on the performance of Darjeeling Mandarin. American Journal of Experimental Agriculture. 12 (4): 1-7.
Hadda, V.G., Mitra, S.K. and Sarkar, D.V. 2014. Effect of micronutrient spray on yield and quality of guava (Psidium guajava L.) cv. L-49. Haryana Journal of Horticulture Science.13 (6): 2-8.

Haldavnekar, P.C., Baviskar, S.B., Raut, R.A., Munj, A.Y., Shedge, M.S. and Sanas, M.P. 2018. Effect of micronutrient on yield and physicochemical composition of alphonso mango under Konkan agroclimatic conditions. Journal of Pharmacognosy and Phytochemistry. 7 (5): 2447-2449.

Hasani, M., Zamani, Z., Savaghebi, G. and Fatahi, R. 2012. Effects of zinc and manganese as foliar spray on pomegranate yield, fruit quality and leaf minerals. Journal of Soil Science and Plant Nutrition.12 (3): 471-480.

Jeyabaskaran, K.J. and Pandey, S.D. 2008. Effect of foliar spray of micronutrients in banana under high soil $\mathrm{pH}$ condition. Indian Journal of Horticulture. 65 (1): 102-105.

Kamble, A.B., Desai, U.T. and Chaudhari, S.M. 1994. Effect of micronutrients on fruit set, fruit retention and yield of ber (Zizyphus mauritiana L) cv. Banarsi Karaka. Annuals of Arid Zone. 33 (1): 53-55.

Khan, S., Singh, H.K., Vishwanath and Pratap Bhanu 2009. Impact of foliar application of micro-nutrients and thiourea on growth, fruit yield and quality of aonla (Emblica Officinalis Gaertn) cv. Narendra Aonla-6.Annals of Horticulture. 2 (1): 83-85.

Krishnamoorthy, V. and Hanif, N.A.K.A. 2015. Effect of foliar nutrition on growth, yield and quality of mango. Journal of Krishi Vigyan.3 (2): 43-47.

Krishnamoorthy, V. and Hanif, N.A.K.A. 2017. Influence of micronutrients on growth and yield of Banana. Journal of KrishiVigyan.5 (2): 87-89. 
Kumar, P. 2002. Managing micronutrient deficiency in ornamental crops. Indian Horticulture. 46 (4): 30-31.

Meena, D., Tiwari, R. and Singh, O.P. 2014. Effect of nutrient spray on growth, fruit yield and quality of aonla. Annals of Plant and Soil Research.16 (3): 242245.

Meena, V.S., Yadav, P.K. and Meena, P.M. 2008. Yields attributes of ber (Ziziphus mauritiana) cv. Gola as influenced by foliar application of ferrous sulphate and borax. Agriculture Science Digest. 28 (3): 219-221.

Mishra, S.M., Ram, D., Pandey, A. and Meena, A.K. 2017. Effect of foliar feeding of micro-nutrients on physicochemical attributes of aonla (Emblica officinalis Gaertn) cv. NA-7 under high density planting. International Journal of Current Microbiology and Applied Sciences. 6 (5): 1-7.

Monika, G., Soorianathasundaram, K., Auxcilia, J., Chitdeshwari, T., Kavitha, C. and Muthulakshmi, P. 2018. Effect of foliar nutrition of calcium and sulphur on growth and yield of papaya (Carica papaya L.). International Journal of Chemical Studies. 6 (5): 765769.

Nehete, D.S., Padhiyar, B.V., Shah, N.I. and Bhalerao, P.P. 2011. Influence of micronutrient spray on flowering, yield, quality and nutrient content in leaf of mango cv. Kesar. The Asian Journal of Horticulture.6 (1): 63-67.

Parmar, P., Patil, S.J., Kumar, S., Chaudhari A.M. and Tandel, B.M. 2017. Response of fertilizer application on growth of papaya var. Red Lady. International Journal of Current Microbiology and Applied Sciences. 6 (12): 2375-2379.

Patel, Y., Yadav, A., Bhanu Pratap, Shivam and Tiwari, D.K. 2018. Effect of foliar spray of micro nutrients on yield and quality of Aonla (Emblica officinallis
Gaertn. L.) cv. NA-6. Journal of Pharmacognosy and Phytochemistry.7 (1S): 1659-1662.

Pathak, M. Bauri, F.K. Mishra, K.B. and Chakraborty, K. 2011. Effect of spraying of micronutrient on growth, yield and quality of banana (Musa paradisiac L.) cv. Martaman. Journal of Crop and Weed. 7 (1): 52-54.

Pawar, R. and Singh, A.K. 2018. Effect of micronutrients and sea weed sap on fruit set, yield and quality of mango (Mangifera indica L.) cv. Dashehari. International Journal of Current Microbiology and Applied Sciences. 7 (12): 397-406.

Premalatha, A. and Suresh, P.R. 2019. Studies on the effect of foliar application of micronutrient mixture on quality attributing parameters of banana (Musa AAB) cv. Nendran. Journal of Pharmacognosy and Phytochemistry. 8 (4): 1036-1040.

Reetika, Rana, G.S., Rana, M.K., Prince and Kant, G. 2018. Effect of foliar application of macro and micronutrients on fruit drop and yield of kinnow mandarin. International Journal of Pure \& Applied Bioscience.6 (2): 1163-1169.

Saraswathy, K.P., Vishwakarma, L.G., Kolambe, S.S. and Sharma, M.C. 2002. Effect of soil and foliar application of micronutrient on growth, yield and quality of sapota (Achras sapota L.) cv. PKM-1.Indian Journal of Horticulture. 57 (3): 215-219.

Shekhar, C., Yadav, A. L. and Singh, H. K. 2010. Influence of micronutrients on plant growth, yield and fruit quality of papaya (Carica papaya L.) cv. Washington. South Indian Journal of Horticulture.48 (4): 6-10.

Shreekant, Ram, D. and Kumar, U. 2017. Effect of foliar application of micronutrients on fruit set, yield attributes and yield of winter season 
guava (Psidium guajava L.) cv. International Journal of Pure \& Applied Bioscience. 5 (5): 1415-1419.

Singh, A.K., Prasad,V.M., Singh, D., Vijay Bahadur; Thomas, T. and Kumar, A. 2018. Effect of different combinations of PGR's and micronutrients on growth and flowering of papaya (Carica papaya L.) cv. Pusa Nanha. Journal of Pharmacognosy and Phytochemistry. 7 (6): 1326-1329.

Singh, D.K., Gosh, S.K., Paul, P.K. and Suresh, C.P. 2012. Effect of different micronutrient on growth, yield and quality of papaya (Carica papaya L.) cv. Ranchi. Journal of Horticulture Science. 5 (1): 351-355.

Soni, U., Thakre, B. and Verma, O. 2017. Effect of micronutrients on growth, vigour and fruit weight of Nagpur Mandarin (Citrus reticulate Blanco) in Satpura Plateau Region, India. International Journal of Current Microbiology and Applied Sciences.6 (8): 435-440.

Subramoniam, S.R., Subbiah, K., Duraisami, V.P. and Surendran, U. 2006. Micronutrients and $\mathrm{Zn}$ solubilizing bacteria on yield and quality of grapes variety Thompson Seedless. International Journal of Soil Science.1 (1): 1-7.

Tagad, S.S., Patil, M.B., Patil, S.G. and Deshpande, D.P. 2018. Effect of foliar application of plant growth regulators and micronutrients on quality of acid lime (Citrus aurantifolia L.) cv. SaiSarbati. Journal of Pharmacognosy and Phytochemistry.7 (5): 745-748.

Thirupathaiah, G., Shirol, A.M. and Sumangala, K. 2017. Influence of micronutrients on growth, yield and economy of sapota cv. Kalipatti under HDP system. International Journal of Agricultural Science and Research.7 (3): 401-408.

Tripathi, D.K., Singh, S., Singh, S., Mishra, S., Chauhan, D.K. and Dubey, N.K 2015. Micronutrients and their diverse role in agricultural crops advances and future prospective. Acta Physiologiae Plantarum. 37(7):1-14.

Usha, K. and Singh, B. 2002. Effect of macro and micro nutrient spray on fruit yield and quality of grape (Vitisviniifera L.) cv. Perlette. Acta Horticulturea.594: 197-202.

Venu, A., Delvadiya, D.V., Makhmale, S.J. and Sharma, L.K. 2014. Effect of micronutrient application on flowering, fruiting and yield of acid lime (Citrus aurantifolia L.) cv. Kagzilime. Haryana Journal of Horticulture Science. 32 (34): 36-40.

Yadav, M.K., Patel, N.L., Singh, P., Choudhary, M. and Nayak, D. 2008. Influence of micronutrients on fruit quality of ber. The Andhra Agricultural Journal.55 (4):515-517.

Zagade, P.M., Munde, G.R. and Shirsath, A.H. 2017. Effect of foliar application of micronutrients on yield and quality of Guava (Psidium guajava L.) cv. Sardar. IOSR Journal of Pharmacy and Biological Sciences.12 (5) Version-VI (Sep. - Oct.): 56-58.

\section{How to cite this article:}

Jat, R. K., Mukesh Kumar, Mohan Lal Jat and Jitendra Singh Shivran. 2020. A Review on Use of Micronutrients in Tropical and Subtropical Fruit Crops. Int.J.Curr.Microbiol.App.Sci. 9(05): 2744-2753. doi: https://doi.org/10.20546/ijcmas.2020.905.315 